\title{
Preface to the 2011 Edition
}

I take this occasion, gratefully, to explain what I wanted to say in this book, and how I came to say it. Since critics often seem to me to have missed the point of my argument, I hope to clarify what I set out to do. How I came to do it is a personal story, but I believe it holds some general interest as a certain type or model of scholarship. An immigrant's tale, it unfolds as a scholar's journey into the complex rhetorical structures that constitute the meaning of America.

My journey began unexpectedly in the course of preparing for Ph.D. orals. In those days, the mid-1960s, you were required to "cover the field," and in American literary studies that included New England Puritanism, though it was an esoteric sub-sub-field, rarely taught, and largely under the province of social, intellectual, and religious history. ${ }^{1}$ So understood, the Puritans wrote in "the plain style." They had rebelled against ornament in any form and expressed themselves on principle in a direct, severely simple language. Their belief that "God's altar needs not our polishings" was repeated, in italics, by every specialist in the field. So it came as a shock to find that Puritan literature was anything but plain. It abounded in images, analogies, symbols, tropes, and allusions; it had recourse to every kind of rhetorical device. I learned from the Puritans themselves that what they meant by "God's altar" was the Bible in all its linguistic splendor. That indeed needed no polishing, and the Puritans made it their ideal for all forms of expression: sermons, treatises, histories, poetry, polemics, personal narratives, even diaries and letters. ${ }^{2}$

In short, I discovered the American Puritan imagination, and with it my dissertation topic. I thank my good luck in retrospect for the freedom of inquiry I'd been granted. No one at Claremont Graduate School (or almost anywhere else) seemed interested in the language of the Puritans; no authority dictated the guidelines of my research. Indeed, it was a chance reading of Roy Harvey Pearce's The Continuity of American Poetry that suggested my particular focus. In a brief survey of colonial beginnings, Pearce noted the epic quality of Cotton Mather's vast, sprawling “Ecclesiastical His- 
tory of New England," the Magnalia Christi Americana. Mather's chronicles, Pearce observed, were history clothed in metaphor, and that "remarkable achievement" warranted literary consideration. Here, then, was a plausible "thesis-problem": the relation in a central Puritan text of rhetorical superstructure to doctrinal substance.

Another major surprise followed. In reading through Mather's epic I realized that the remarkable point-to-be-explained was not that Mather had clothed his argument in metaphor. It was that his argument was metaphor. The "great works of Christ" he celebrated were figures of the imagination. The Magnalia's people and events, though based on historical record, came alive as part of an intricate symbolic system. To paraphrase Marianne Moore's definition of poetry, Mather's Puritans were real toads in an imaginary garden. And the name of the garden, "America," was a sweeping rhetorical construct, one that opened into a narrative conflating communal, personal, geographical identity - the destiny of New England, the character of representative Americans, and the prophetic design of the New World.

Thus my inquiry into a rhetorical mode led me into a historical fantasy. The newness of this New World defied, indeed reversed, the common-sense meaning of new. I proceeded to read through other colonial histories for comparison and found, predictably, that New France, New Spain, and New Amsterdam were new in the sense of replica, imitation, or offspring. Their authors - explorers, missionaries, settlers - celebrated the cultures of Renaissance Europe. Even when they condemned the effects of conquest, they promoted the social structures and belief systems of the "parent country." Mather, on the contrary, describes a venture destined to supersede a corrupt Old World. Rhetorically, he transfers the imperial center from Europe to the American strand. His New England opens a new stage in world history. The Magnalia begins by invoking Virgil's Aeneid, and that parallel to the founding of Rome only hints at the scope of his epic design. As the narrative unfolds, the Puritan Great Migration stands revealed as the latest in a series of "dispensations," progressing from one "elect people" to another, from Old Israel to New, and then forward from the early church to the Protestant Reformation to this New Israel, harbinger of still greater "things to come," for America first and then the world. 
This sweeping vision I found reiterated throughout the literature. It was not of course the only form of the colonial New England imagination, as Mather's account of the colony by no means encompassed all aspects of the Puritans' experience. But it was a prominent and sustained form of their rhetoric. Mather began the Magnalia in 1692, when the colony's independent charter was revoked, and he published it in 1702, when New England moved officially from colony to province, from Puritan control to direct royal governance. Reading back, however, from Mather's epic to the corpus of New England writing, I realized that the Magnalia marked not the end of an era but the culmination of a literary tradition, one that had developed across the century, from one generation to the next, one doctrinal shift to another, in virtually every genre and on virtually every kind of occasion. In Mather's epic it embodied the triumph of visionary language over the actual course of history. In general, it issued as a rhetoric that lifted New England, past, present, and future, into the realm of the imagination - or rather, the theological imagination, as the theologian Herbert Schneider (an "outside examiner" on my orals committee) sternly pointed out.

That necessary qualification required me to reach beyond the Puritans to the legacy they had inherited of Christian hermeneutics. Once again, my research turned out to be a journey into a strange new world. I knew that Christianity had divided the Bible into Old and New Testaments. But as a secular Jew I now confronted the stunning implications of what I'd assumed to be a chronological distinction. The oldness of the Old Testament testified to the world-changing powers of interpretation. This was not the familiar appropriation of cultural treasures by a conquering people. When the Romans renamed Zeus as Jupiter they reaffirmed the Greek gods by adapting them to a new cosmology. In this case, conquest left the old names intact but transformed their import. Adaptation was subjugation. By exegetical fiat, the newness of the Christian New Testament had absorbed, reconfigured, and usurped the very meaning of the story of the ancient Jews.

I followed the process of usurpation with "wild amaze": through a kind of imperialism by interpretation, one scriptural story had been made the colony of another. A wondrous textual world of chronicle and prophecy - of wisdom literature, poetry, legal and 
moral commandment, heroic saga, even the erotic Song of Songs had been appropriated from start to end as the narrative of origins for a new chosen people. Spiritually interpreted, the "merely literal" Hebrew Scriptures opened into a procession of prefigurations of Jesus: Adam's Fall, a prophecy of the messianic New Adam; the Red Sea, a figure of Christ's Baptism; the sacrifice of Isaac, a type of His crucifixion; Jonah in the whale, a promise of His resurrection; the twelve tribes, a foreshadowing of the Apostles, fathers to God's new "elect people"; and "all the prophets," from Isaiah to Malachi, harbingers of "the thousand-year reign of Christ on earth, hence called the millennium."

I recognized in this hermeneutic the ground of the symbolic tradition in Western art. It had seemed adequate before to ascribe it loosely (and loosened from its theological moorings) to "religious tradition," the legacy of Christian belief to the modern imagination. But in this case it applied to a modern group defined by its theology, and I set out to explore that legacy as the long foreground to the Puritan imagination, from the Church Fathers (often quoted by the Puritans) to the Reformation. It was a history of fierce polemics, I learned, which had gradually coalesced into an intricate, comprehensive system of spiritual interpretation. By 1500, hermeneutic doctrine had merged the Old and New Testaments into a cosmic narrative of the progress of the Catholic Church. Luther's revision involved a revolutionary inversion of tradition. The Catholic Church, he announced, was in fact Christ's mighty adversary the Antichrist ("scarlet whore of Rome") foretold in the Books of Jeremiah and Revelation. Its thousand-year reign was foreshadowed by the Egyptian and Babylonian captivities. Spiritually understood, the true heir to Israel was the Protestant Reformation. And as such, by a common exegetical mode called typology or figuralism, they "typed forth" (prefigured, forecast) the progress of the Protestant "Church Invisible Universal" to the millennium.

It was scriptural typology above all that shaped the Magnalia's vision. What the American Puritans added to Protestant millennialism was in part an extension of that hermeneutic - tradition used to reinvent tradition - and in part a violation of its very premises. For by those premises, reaffirmed ex cathedra from Augustine to Aquinas to Luther, and reinforced with legal severity by Calvin, spiritual meaning applied exclusively to the realm of the spirit. It 
concerned redemptive history (the soul's journey to God and the trials of the Church) as distinct from secular history (geographical place, the chronicles of kings and peoples). The New England Puritans swept away that crucial distinction. In their "special commission," they proclaimed, redemptive merged with secular history. With an arrogance that astounded their contemporaries, Protestants no less than others, they identified America as the new promised land, foretold in scripture, as preparatory to the Second Coming. They proved from Scripture texts that their migration to New England was a flight from another Babylon or Egypt (meaning not only a false religion, but, morally and socially, European civilization); their conflicts with the local "savages" were "Wars of the Lord," foreshadowed by Joshua's conquest of Canaan; and the New World would in due time be the site of New Jerusalem, which Mather therefore hailed as "Theopolis Americana." That figural world-redemptive design is the high argument of Mather's epic. It explains the Magnalia's substance and texture, unites its omniumgatherum structure, and accounts for its form and content.

My thesis was done. But well before I'd finished I realized that I'd launched upon another, broader area of inquiry. I refer to the striking symbolic conjunction of "New England" and "America." This resonated with my immigrant sense of wonder, three years before, at the language of America. I'd known of course that the United States had somehow arrogated the American identity for itself, but now I confronted the glaring contrast this implied between rhetoric and reality. Here was a modern liberal society, with the secular values of other modern liberal societies (rule of law, freedom of speech, equal opportunity), as well as the blatant de facto affronts to those values that characterized other modern liberal societies (racism, economic inequities, ethnic discrimination) - a liberal capitalist nation not unlike others, which had identified itself, rhetorically, as the new promised land, and had persuaded its extraordinarily diverse population (all but the native Indians, now confined to reservations) to believe in themselves as a New Israel.

It was not the chauvinism that struck me; this was a staple of nationhood. It was the power of an identity based on a denial of history. The scriptural sources of that rhetoric were all too familiar: I had just spent several years on a socialist kibbutz in Israel. (My 
first impression of these Puritans was that they were seventeenthcentury Zionists sailing in the wrong direction.) But Zionism was grounded in genealogical continuity and specificity of place. Even as the Jewish religion had developed its own tradition of spiritual exegesis, including a form of typology, it defined Jewishness historically, "sanctioned by" genealogy, and the "Jewish Homeland" geographically, in collaboration with archaeology. The rhetoric of America worked in precisely the opposite way. It united a more or less random gathering of emigrant groups under an identity of newness, and declared as preordained its dramatically, sometimes arbitrarily, shifting boundaries, from thirteen East Coast states to half a continent. By what secret formula had that heterogeneous people acquiesced to a transparently made-up story? Not only acquiesced: they had embraced it with a truly spiritual fervor.

My thesis was my passport into a profession; the questions it raised about "America" became my passport into the culture. What others around me held to be self-evident I considered a puzzle to be solved. Part of that puzzle concerned the Puritans themselves: why did they figure so prominently in the national consciousness? The plain fact was that "American Puritanism" had expired long ago: New England, even in 1776, occupied a fraction of what was to be the United States; the Calvinism often associated with "Puritan America" was a broadly Protestant phenomenon; and even as a pejorative, "Puritan" was applied only to the United States - but not, for example, to England, whose epic poet was Milton, where radical Puritans had formulated an ideology of liberty, and where under Cromwell the Puritans had actually gained national control for a time. Above all, the Puritans represented both theocracy and the past in a nation that defined itself by democracy and the future. How was it, then, that U.S. histories celebrated the Puritans as forefathers of the country, that their Thanksgiving Day had become a national holiday and the Mayflower a national emblem, that these apologists for intolerance were acclaimed as champions of freedom, that of all immigrant groups it was mainly the Puritans that mattered in American literary studies? In sum, why was it that the Puritans were integral to the meaning of America?

Now I believed I had a clue to the solution. In the United States, both "Puritan" and "America" - like Mather's "New England" were creations ex verbo, linked by a narrative of mythic newness and 
sacred-secular mission. The magnalia Christi Americana had evolved from an "errand into the wilderness" to the continental sweep of "manifest destiny." And the divinity that shaped those ends had expanded, proportionately, from the Puritans' Christ to a malleable "Creator" - the Jehovah-Jesus of Judaeo-Christianity, the Enlightenment Deity ("Newton's God"), the Romantic Spirit of Natural-Supernaturalism ("Nature's God"). No doubt historians had described the history of colonial New England accurately enough, but its legacy to the culture was the Puritan imagination.

When I said this in a job interview at Berkeley, Henry Nash Smith, a founder of American Studies, asked how I could account for that legacy. Myth and symbols emanated from historical facts, such as the frontier experience. Perry Miller had written the social-intellectual "history of declension," definitively documenting the rise and fall of the New England "Puritan Mind." Through what "ether," Smith asked, had the "Puritan influence" passed down through the centuries? I had no ready answer, but I had found a new challenge. For clearly myths and symbols were more than reflections or representations; they also served to create realities. My task, then, was to explain rhetoric as fact, to locate the proof-texts of national continuity. This required conflating literary and cultural history, extending the concept of the literary to include all written statements about the nature and purpose of the Republic. It meant undertaking a cultural close reading of popular and high literature, sermons and histories, July Fourth orations and protest manifestoes.

In other words, I embarked upon an exploration of the textual America: a changing yet persisting narrative-persisting because changing (flexible, adaptable) - that shaped a living culture. I recognized from the start that I was running a certain risk: I would have to bypass "real" history. My assumption, though, was that those realities were self-evident, a matter of open record and common sense. Obviously, the New England Puritans were a seventeenthcentury Protestant sect, itself divided into several, now obscure "orthodoxies." Obviously, the United States had legalized the separation of church and state. Obviously, John Locke, republican ideology, and Scottish Common Sense philosophy had guided the Founders, and the frontier had been driven forward by economic factors and secular visions of progress, such as the European concept of the course of empire. 
But it seemed just as clear to me that the Puritan rhetoric had made history in its own right. And that history now enticed me in the form of an archive of extraordinary richness and unparalleled accessibility. All nations have their distinctive myths, heroes, and historical landmarks, but as a rule those foundations lie in the remote past, shrouded in legends of the supernatural and multiple oral traditions. In the United States, the foundations were visible at every stage of construction, in published modern texts that spanned only a few hundred years. Here, you could follow the making of myth and symbol step by printed step, from definition to revision, sometimes from insertion to deletion to reinstatement. You could specify how certain documents, along with certain heroes and villains (and not others), had been canonized; how certain symbols had taken hold as others fell away; how certain places and events (Plymouth Rock rather than the Jamestown Landing) had been rendered iconic; how a certain group of contentious men had been harmonized as Fathers of the Country; how the Declaration of Independence and the Constitution had been declared sacred texts, in spite of anti-Jeffersonians and anti-Constitutionalists, as well as a decades-long course of rancorous debates and reluctant compromises. Here, in this forever emergent, constantly self-scrutinizing, self-consciously new country, the process of cultural formation stood open in plain sight, in a heterogeneous collection of fiction/nonfiction which might be titled, after another of Cotton Mather's compendious works, Biblia Americana.

What struck me first about this Scripture was that "America" stopped short at the Canadian border - that indeed it excluded most of North and South America. I had grown up with the rhetoric of Canada, which, for all its extravagance ("land of hope," "land of liberty"), identified the country by common-sense geography (the continent's "true North, strong and free"). Canada's official landmarks and cultural icons attested to the persistence of European traditions; the symbol of its West was a Royal Canadian Mountie; its foundational stories told of French explorers and British generals; its storied text of nationhood was the British North America Act. In America's foundational story, by contrast, all marks of colonization faded into a mission to renovate, not recapitulate, the ways of the Old World. A series of Puritan histories of the colony, beginning with Captain Edward Johnson's Wonder-Working Providence of Sions 
Saviour (1654), explained to the world that "Christ's Kingdom was [our] mainspring of motivation and that which gave the Name to New-England . . . according to predeterminate Design." And that design, according to John Winthrop, the colony's first governor, designated New England "as a city on a hill": its predecessor was the scriptural Jerusalem; its telos, the New Jerusalem of the Resurrected Christ. The basic structure of that story remained intact through three centuries. It told of a flight from tyranny, a "great migration" to a new site of redemption, which reversed cultural dependency into a forecast of national independence.

Surely, here was a proof-text of influence. The Puritans had provided a myth of origins designed for a fledgling republic intent on breaking free from the "tyranny" of empire and the past. Another, equally formidable proof-text was inscribed in the Puritans' "errand into the wilderness." That image was prominent enough for later historians to have equated it formulaically (as history clothed in metaphor) with the colonial venture. The Puritans, they explained, were on an errand from England, with the message of Reformed Christianity. The Puritans themselves had a more ambitious plan in mind. This was not $a$ wilderness for them; it was the wilderness. Unlike the Australian outback for the British, or the South African veldt for the Dutch Calvinist Boers, this wilderness was the place of prophecy and revelation, prelude to a land of promise. Their image built upon a striking configuration of wandering and possession - wandering with a telos in sight and therefore possession guaranteed. Implicitly at first, and then with astonishing directness, that Puritan guarantee evolved into a nation's divine right to expand. When from 1630 to 1690 the Puritans spread through New England, America was in fact the site of European imperial rivalries. So it was, too, in 1776, when Britain held vast territories in the northwest, France in the southwest, and Spain in the south and west. By that time, Canada had expanded "from sea to shining sea" by force of "foreign arms," as had Mexico.

The United States was the exception. Here the forces of expansion represented an American empire. By right of origins, the United States, the "country of tomorrow," had the duty to "go West." Elsewhere, "frontier" meant "stop: no trespassing"; here it was a directive to the future, a green light to "the last and greatest of human dreams." U.S. struggles against European armies were 
wars against foreign powers; its Indian wars signified not land grabbing and genocide but a promise redeemed. Its expansionist imperative, as Jefferson declared it, derived from "that Being in whose hands we are," who led "our fathers, as Israel of old, from their native land and planted them with all necessities and comforts of life." There he found "divine guidance" for the Louisiana Purchase (through which the country then doubled in size) and for the Oregon Expedition from Pennsylvania and Virginia across the Appalachians to the Pacific. A decade earlier, Jefferson had spoken as a Virginian republican for states rights and limited democracy. Earlier still, on July 4, 1776, he had proposed for the Great Seal of the United States an image of "the children of Israel in the wilderness, led by a cloud by day and a pillar of flame by night," and to that vision he returned in 1801. As newly elected president of the United States, he followed the scriptural design set out by New England's Puritan "fathers."

For the Puritans, the wilderness promise had no boundaries at first except the New World. Canada and Spanish America found their place in sermon prophecy as part of the Satanic American darkness to be reclaimed. Speculations about the millennial site shifted from New England to, vaguely, "America itself." In 1697, Judge Samuel Sewall proved typologically, at length and with formidable scholarship, that New Jerusalem would descend somewhere in South America, and his prediction reverberates throughout the next centuries. "As the Great Almighty gave them [the New England Puritans] the Land of the Heathens, so our New Canaan of Liberty must redeem the Land of heathen Catholics": that was the appeal to invade French Canada in 1754, and it turned south (to other lands of "heathen Catholics") in the MexicanAmerican War of 1846 and the Spanish-American War of 1898, adding territories as distant as Texas and Hawaii to the Union. The historical landmarks in this process were the Monroe Doctrine of 1823, prohibiting "Old World powers" from interfering in New World affairs, and its Roosevelt Corollary of 1904, granting the United States the right to save Latin American countries from evil influences from within or abroad. The imperial adventures these edicts entailed reached from Panama to the South Pacific. What remained consistent $-\mathrm{a}$ ritual summons forward, a continuing 
narrative of mission that fused past and future - was the rhetoric of the errand.

In the twentieth century, the dominant rhetoric refocused to center on the concept of the city on a hill, beacon to world. By then Sewall's prediction had faded into the nostalgia of utopian novels. Officially, the limits of "America" were set within the boundaries of fifty United States. The rhetoric of errand was now a summons to make the world "safe for democracy." America was "freedom's model in a searching world"; its destiny was manifest in the global spread of America's "universal principles" and, in John Kennedy's "new frontiers," in the cosmic reach of American enterprise. And of course the rhetoric of territorial rights remained intact throughout. As Robert Frost put it, in his poem for Kennedy's inauguration - recited soon after Kennedy had hailed America as the "city on a hill," explicitly citing Winthrop's inaugural lay-sermon of the Great Migration (1630) - "The land was ours before we were the land's / She was our land ... / Before we were her people"; we "found salvation" when we "gave ourselves outright . . . / To the land vaguely realizing westward / . . Such as she was, such as she would become."

From Winthrop to Frost, then, the rhetoric of expansion was prefigured in the American Puritan imagination. It had passed from colony to province through revival meetings that "awakened" all thirteen colonies to a common faith, and so (historians agree) helped to mobilize the forces of revolution. Jonathan Edwards, leader of that Great Awakening, was the major figure here - and for me a major discovery. I knew him from the scholarship as an important philosopher, a great Calvinist theologian, a fervid fireand-brimstone preacher, and the prescient pre-Transcendentalist spiritualizer of Newton's "Book of Nature." What I found, in numerous apocalyptic treatises, was also a relentless interpreter of current Americana, in political, economic, military, and even naturalist detail. In newspaper reports of the "changing course of trade," in bulletins of victory in the French and Indian wars, he saw proof of "what is approaching in spiritual things, when the world will be supplied with spiritual treasures from America." (At the time I read this, I heard its echoes in the rhetoric of the Vietnam War.) And in the Great Awakening itself Edwards found firm evi- 
dence that "the sun of the new heavens and new earth ... shall rise from the West, contrary to the course of things in the old heavens and earth," revealing "America, a brighter type of heaven."

By that light, Edwards's grandson Timothy Dwight, a leader of the Revolution, wrote the first epic of the United States, The Conquest of Canaan (1785), featuring George Washington as Joshua. Inspired by that vision, Emerson forecast the time ("and perhaps that time already is") "when the sluggard intellect of this continent will ... fulfill the postponed expectation of the world" (italics mine). The address in which he elaborated that prospect, "The American Scholar," was soon canonized as "America's Intellectual Declaration of Independence." The year was 1837, when "this continent" reached no further than Michigan, the Union's twenty-sixth state. Two years later, John O'Sullivan sanctified the continuing westward movement as manifest destiny, and popular writers began to celebrate the pioneer - in an image as alien to the South American gaucho as it was to the mounted Canadian policeman - as a Moses leading his people to what by divine fiat was already theirs.

The sheer power of that rhetoric seemed now to me to account for another puzzle I'd encountered: even the most astute European minds had been blinded to history in this case. Karl Marx declared that its "vast empty spaces" made America "exceptional" among modern nations. The German landscape artist Albert Bierstadt joined an armed expedition to record the Rockies as epiphanies of a "new heaven and new earth." Alexis de Tocqueville, the French aristocrat, wondering at America's "continuous progress" over the "empty continent," concluded that it constituted nothing less than a "providential event ... unabatedly and daily driven forward by the hand of God." Its primum mobile, he added, the "origin of the Americans ... their point of departure," lay in the Great Migration: "I can see the whole destiny of America contained in the first $\mathrm{Pu}$ ritan who landed on these shores, as that of the whole human race in the first man." Evidently these sophisticated foreigners had also come under the enchantment of the rhetoric. And their enchanted "observations" had in turn cast their spell on American historians and critics.

More conspicuously still, that spell had shaped the terms of immigration and acculturation. To become American was by definition open-ended, your personal entry into a new identity. I'd 
heard of that prospect often enough, but now I had a clear view of its imaginative scope. Elsewhere, immigrants had to become someone else: Turks in Berlin, German; Moroccans in Paris, French; Pakistanis in London, British. But to become American was to be spiritually reborn, your old identity washed away in transit to the New World. The American self that emerged was your own, liberated from the restrictions and constrictions of the past to unfold without limit, according to its potential, and in accordance with the prospects of renewal and open opportunity of a New World. As Stanley Kowalski shouts at Blanche DuBois in Tennessee Williams's A Streetcar Named Desire, "I am not a Polack! People from Poland are Poles! . . . But what I am is one hundred percent American. I was born and raised in the greatest country on this earth, and I'm proud of it!"

Well into the twentieth century the symbol of Americanization was the melting pot. With the 1960 s civil rights movement, that symbol began to shift in meaning. National protests exposed much of what had not melted into America, the many "minorities" excluded from the Dream. And over that decade and the next, protest gradually extended into affirmation. America was the land of minorities, after all, of immigrants and what remained of the Native Americans, and each group had contributed in its particular ways to the culture; indeed, those contributions together constituted America. "We are all multi-cultural now," went the refrain, meaning "we are all hyphenated Americans," and accordingly Americanist scholars moved from broad analyses of America (such as mine) to what might be called hyphenation studies: specialized research into African-American culture, Italian-American culture, AsianAmerican culture, Latino/a-America culture. Some claimed that this "heterogeneity" pointed to a radically un-American paradigm: diversity as against the e pluribus unum credo of the melting pot. But as a Canadian immigrant, I could not help noting the familiar rhetorical work of "American." The term "multi-cultural" had been coined long before in Canada, and officially instituted not as an ideal, but as a recognition of diversity: the facts of contrasting or conflicting regional and ethnic affiliations (French in Quebec, Scottish-Irish "Newfies," Midwestern Ukranians) that thwarted or diffused national identity, and at best coalesced in mutual tolerance. In the United States the hyphen that announced multiplicity 
served to incorporate; even as it acknowledged hitherto-excluded cultural legacies, it marked the entry of those hitherto-excluded groups (for example, "Indians" as Indian-American, then Native American; "negro" as African-American) into the dominant culture.

On a practical level, multi-culturalism issued in competing claims of importance in the formation of America and demands for equal representation. And to judge by the rhetoric of those claims and demands, Multi-Cultural America seemed to me a globalized open-market version of the city on a hill. Indeed, its premises had been articulated by an advocate of the melting pot, the Russianborn Jew Mary Antin, in her autobiography, The Promised Land (1912): "No! it is not I that belong to the past, but the past that belongs to me. America . . . inherits all that went before it in history. . . . Mine is the whole majestic past, and mine is the shining future." Rhetorically, America absorbed all cultures, creeds, and traditions. As the "nation of nations," it invited the "majestic past" as it were to participate as the American Way to the Future. The American newness was a rhetorical design in which a fresh start signaled a historical culmination. And the key to that design, here as before, was the colonizing hyphen in "Judeo-Christian" - which is to say, the cultural work of the Puritan figura. The creative power of the "Old Testament" was nowhere more evident than in its appropriation by the "New," and it was precisely that enveloping embrace which allowed Christianity so fully to appropriate it. By that strategy the rhetoric of America had appropriated traditional concepts of progress, secular and religious, and by that strategy now it embraced the heritage of its heterogeneous immigrants. Elsewhere, hyphenization in the modern world meant contradiction or conflict: African-British, Asian-Dutch, Latino/a-French. In the United States, the hyphenated American was not only the norm, but a national ideal.

For personal reasons perhaps, the case of Jewish-Americans seemed to me particularly telling. Jews had assimilated all too readily in modern times - shed their shtetl past with all the enthusiasm unleashed by the Enlightenment to reinvent themselves as French politicians and businessmen, Austrian writers and musicians, Hungarian mathematicians and fencers, German scientists and philosophers, English businessmen and politicians. Jews in America had 
also followed that pattern: hidden their origins, changed their names, "blended in." But as Antin's Promised Land indicates - and many works before it, including the canonical "New Colossus" (1883), by the American-born Jew Emma Lazarus - the rhetoric of America opened a different route to assimilation. Increasingly, Jewish immigrants recognized their special entry to the culture, and after the Second World War recognition became reality. As the oldnew people of God, Jewish-Americans found direct access to the Biblia Americana.

The result was a model of Americanization. I first saw it in the buoyant Great Immigration literature of 1880-1920, where shtetl roots flowered into fresh forms of the Dream so that Yiddish itself found a place in what David Levinsky called the "marvelous transformations" of "this land of milk and honey." Across the twentieth century the specifically Jewish-American transformations found expression in every cultural domain: in a Hollywood "dreamworks" dedicated to "preserving and celebrating American values"; in a major literary tradition - reaching from Henry Roth to Philip Roth, and including Singer, Malamud, and Bellow - that built upon the complexities embedded in the hyphen linking "Jewish" and "American"; in the development of a neoconservative orthodoxy that made Jewish tradition a commentary on American millennialism; in comic-book superheroes (Superman, Captain Marvel, Captain America); in the evolution of a new American type, "New York Jew"; and in a variety of popular figures, exemplars all of the hyphenated American, from radio-show "Molly Goldberg" to the "Yenglish" stand-up comics (from Jack Benny to Woody Allen) who helped redefine showbiz, along with a string of hit-song perennials, such as "I'm Dreaming of a White Christmas," "Yankee Doodle Dandy," and "God Bless America."

For all these Americans, the hyphen that identified the past was a sign of acculturation through reciprocity - cultural reciprocity that facilitated national assimilation. Jewish-Americans were exemplary, not unique, in this regard. Philip Roth draws a vivid contrast between "self-muting" English Jews and American "Jews with force ... with appetite, Jews without shame... . Unaccommodating Jews, full of anger, insult, argument, and impudence," and the same might be said, with adjectives appropriate to their different 
ethnicities, of Italians, Irish, Chinese, Mexicans. Each immigrant group found its distinctive way to shape America as they immersed themselves in it.

Rhetorically, the America they shaped may be traced in two national addresses that marked the shift from the melting pot to the multi-cultural model. The first was Martin Luther King's (rapidly canonized) civil rights address of 1963. The Dream, he declared, was his as an African-American and by extension was also the legacy of all Americans hitherto excluded from "our republic." It was their "promissory note" - a socioeconomic debt based on a spiritual promise, "a sacred obligation," inscribed in "magnificent words in the Constitution and the Declaration of Independence," and guaranteed by notes of prophecy: "One day every valley shall be exalted and ... the crooked places will be made straight and the glory of the Lord shall be revealed." Two decades later, speaking in King's scriptural cadences - "bound by Dr. Martin Luther King, Jr., and Rabbi Abraham Heschel, crying out from their graves" - Jessie Jackson called for a Rainbow Coalition to accommodate the country's manifold constituencies. "Our flag is red, white, and blue, but our nation is a rainbow - Red, Yellow, Brown, Black and White," he declared. "The Rainbow Coalition is making room for Arab-Americans ... Hispanic-Americans . . Native Americans . . Asian-Americans. .. . It is often said that we live in a great nation, and it is, but it can be greater still. The Rainbow is mandating a new definition of greatness" - a mandate for "the nation to fulfill its mission," for a "leadership that can lead our Nation in the direction of the promised land. ... America, our time has come." The proof-texts here of continuity through change were remarkable not only in general terms but in their particular sources. The prophecy that King invoked (Isaiah 40:4) - the Dream fulfilled as the wilderness redeemed - was a key sub-text of John Danforth's Errand into the Wilderness (1670); the rainbow Jackson spoke of, recalling the promise to Noah of a renovated new world, was a staple of New England Puritan election-day sermons. That figure or type had once applied, in medieval exegesis, to the Virgin bearing Jesus, and in Protestant hermeneutics to the Arc of the Reformed Church. For the Puritans it recalled their own transit, under God, to a New World. In Jackson's campaign speech, it represented the hyphen- 
ated American, pregnant with promise, on a Noah's Arc bound towards a "new definition of greatness."

At this point I became aware, again with an immigrant's surprise, of the extraordinary power of religion in the United States. Perhaps the most vital contribution of the Puritans, I realized, was to have endowed America, as New Israel, with the spiritual bonds of community. No doubt the thirteen states had united under a legal contract, but the American identity it had secured for itself derived (in Leo Strauss's term) from a politico-theological context. "Mad King George" my have warranted every complaint leveled against him, but in 1776 the only divinely sanctioned form of government in the West was monarchy. The concept of the divine right of kings built upon an intricately developed spiritual tradition, a cosmic hierarchy embracing God and man, male and female, father and family, ruler and people. Liberal democracy had the authority of reason, but the hard fact is that all communities, modern no less than premodern, have a deep need for spiritual purpose, for a "higher authority" to underwrite reason, some transcendent sanction as the ground of cohesion.

The leaders of the new republic found all this in the malleable narrative they inherited of "redeemer nation." It was not by accident that Jefferson, Adams, and Franklin proposed the Red Sea Crossing as the country's official emblem, that a member of the Continental Congress suggested Hebrew as its official language, or that the most popular patriot oration of 1776 was Samuel Sherwood's The Church's Flight into the Wilderness. Nor was it by chance that in his first inaugural address (probably written by Hamilton and Madison) George Washington declared that "Heaven itself has ordained" the new republic, and then, reviewing the progress from Revolution to Constitution, announced: "Every step . . . seems to have been distinguished by some token of providential agency." Shortly after, at the request of Congress, he proclaimed a Day of Thanksgiving and Prayer that would become a national ritual.

What these Enlightenment statesmen (Deists all) understood entailed far more than the conventional mode of invoking God to authorize secular policy. They grasped, as it were by cultural reflex, that the Puritan Biblia Americana, unlike the Bible, was not a story 
told once and for all - in days of old, when God spoke directly to man (before Christ, to Moses and the Prophets, and after them as Christ): spoken, inscribed, and now sealed in an infallible Sacred Text. "America" was something new under the sun. This "Bible of the Free" (as Melville called it) told, was telling, an open-ended story, one that was therefore available for reinscription in accordance with changing conditions. For as Americana those changes carried the gospel tidings of a Scripture in process, still to reveal its full meaning.

As a model of interpretation, this revision of tradition held radical new possibilities. Catholicism had claimed Scriptural prophecy for Christianity but kept both the Bible and its prophecies from the world as the exclusive property of a clerical elite. Protestants had opened the Bible to the world and prophecy to current events, as leading to the millennium, but they kept that prophetic process within Scriptural bounds. The New England Puritans went one step further. They opened the very concept of Scripture to the modern world, as the Testament of the End-Time. One key to that dramatic innovation was embedded in the figural meaning of newness. The errand resonated with the wilderness of Moses and Jesus, but as a new errand it opened a post-Biblical set of meanings: a new world, a new people of God, a new land of milk and honey, a new road to New Jerusalem, the American Way. To make things new defined the American process toward the millennium. And the newness applied by extension to the millennium itself. It, too, though long prophesied, was open-ended. It changed with new concepts of mission. Mather's "post-millennial" reign of Christ, the Kingdom of God, became Edwards's "pre-millennial” heaven on earth, a thousand-year unfolding of scientific wonders, and that telos was made new again after independence as the universal reign of Enlightenment Reason, which was still later spiritualized as Emerson's "nation of individuals" yet to be.

I recognized in that extraordinary capacity for accommodation a variation of figural strategy of incorporation. As the road to an open future, the American Way could absorb virtually any set of beliefs, including even Roman Catholicism - the "Great Beast" of the Reformation - provided that it adapted to the tenets of manifest destiny. All creeds and traditions were welcome as testimony and witness to the New World Scripture; all the practical or con- 
ceptual changes required by new arrivals were festively endorsed with a caveat. "America is for change," as a July Fourth orator put it in 1850, "so long as it is change we can believe in." That emphatic qualification (reiterated by many others, on many other occasions) carried an important directive, with important implications: for all its universal claims, the American Way led to a particular destiny. It was a teleology circumscribed (like all others) by a distinctive culture - in this case, the ideals compatible with modern global capitalism. But within these nontranscendent limits, the American Dream flowered with immemorial vistas of utopia.

Open (but destined) means, final (but malleable) ends: through that rhetorical dynamic the American Way found perhaps its most popular expression in the twin ideals of the Declaration: "the pursuit of happiness" and "a more perfect union." I speak not of Jefferson's intention but of cultural intentionality: the rhetorical process by which the Declaration of Independence was declared the cornerstone of a Novo Ordo Seclorum. The pursuit was variable, "on the way" - and as such it was inscribed "by the Creator" with the Truths of a perfect union. And that union, though an ideal, was still in process - and therefore it was always, open-endedly "more" perfect. "In the beginning was the Word" stood as the full and final revelation of a closed Holy Book. In the United States, the Word became free-enterprise democracy, and the Constitution's "We, the People" became enshrined in press, pulpit, and political platform as "Nation of Futurity." James Madison, the great theorist of The Federalist Papers, declared that we must defend "our political scriptures" with "holy zeal," and soon after, John Quincy Adams explained: "the birth-day of the nation is indissolubly linked to the birth-day of the Savior . . . the Declaration of Independence first organized the social compact on the Redeemer's mission upon earth. .. . It laid the cornerstone of human government upon the ... pledge of the fulfillment of [Hebrew] prophecies announced directly from Heaven."

By mid-century, after long and heated debate, The Federalist $P a^{-}$ pers had itself been canonized as a "political scripture," and the historian George Bancroft set out to document its narrative context. The story he told shifted in content as one volume succeeded another from 1854 to 1878 , but every shift concluded with a present in which "our promise ... remains unfinished, unfulfilled, but 
still ... the most successful realization of humanity's universal hope." His monumental History of the United States-an updated Magnalia Christi Americana ${ }^{3}$ - became the country's "official history," illustrated for school editions with icons of national heroes (the Puritans' "Flight to Freedom," Washington in "Prayer at Valley Forge," Lincoln-Christ redeeming the grateful slave). The documentation, as Bancroft insisted, was "scrupulously empirical," but his was reflexively typological: the Puritan Migration (which "fathered our freedom") stood as the Old Testament to the New Testament revealed in 1776. And as revelation, instated in Temples of the Law (where the separation of church and state stood as a sacred ordinance), the old-new rhetoric helped ensure continuity through the two great crises of national formation. During the creation of the Republic, it worked to domesticate an explosive radicalism by redefining revolution itself, in this special instance, as an inevitable spiral forward, part of the upward "course of human events" that included Moses' revolution against idolatry, Christ's against the Mosaic Law, and Luther's against Papal Antichrist. And through the mid-nineteenth-century crisis of compromise and secession - the Union's "great trial by fire and blood" the same recourse to revelation helped unite the country through Civil War (not in spite of but by means of holy conflict). "My eyes have seen the coming / Of the glory of the Lord," went the "Battle Hymn of the Republic"; "His Truth is marching on." This was no "war between the states"; it was an apocalyptic event that made manifest, as never before, that America (in Lincoln's at first overlooked but then iconic phrase) was the "last, best hope of mankind." 4

In Europe, the Enlightenment had inspired many new declarations and constitutions, but as a national self-redefinition not one of these survived revolution and counterrevolution. French identity returned to the grandeur of its past, to Louis the Sun King and the flowering of the French language. The ideals of a newly formed Italy reverted to some putative fusion of the Greek spirit and Roman law. So it was too, mutatis mutandis, in Germany under Frederick the Great, and in Russia under Catherine the Great, for all the influence at court of Voltaire and Montesquieu. The millennial vision of Pan-Slavism was grounded in the "folk" and the Eastern Orthodox Church; England's diminished monarchy continued to 
unite a nation that defined itself through traditions reaching back beyond the Norman Conquest and the Magna Carta. The United States became the only truly "new nation" because its practical, pragmatic, no-nonsense, go-getting, businesslike people believed in the spiritual identity they had inherited.

The transparent link here to ideology (whether in the Marxist or the anthropological sense) invited analysis. But I decided to leave that project for the future. ${ }^{5}$ My concern remained with something compelling and complex enough: a religio-modernist rhetoric that had provided the faith for the American Way. I saw its imprint all around me in the ideals ("Truth," "Justice") that - as pulpit fare (Protestant, Catholic, Jewish) no less than in comic books - were made synonyms for the American Way. I heard it echoed in various social rituals "under God" and read it in statistical surveys of religious belief ( 87 percent believe in heaven and hell, a majority of Americans believe that God has granted America a special role in human history). That religio-modernist faith formed a basis both of "the anti-intellectual tradition in America" ("a thorough knowledge of the Bible is worth more than a college education" was Theodore Roosevelt's maxim) and of the Transcendentalist ideal of intellectual self-realization ("God is within you," Emerson urged his lyceum audiences; "there is the celestial host"). Moreover, as I learned firsthand after a lecture I gave at Brigham Young University, the Word as America had actually been made incarnate a century before in a brand-new religion, with its own newfound Biblia Americana, acclaiming an elect white people as the native Americans, and inspiring a set of upstate New York prophets to guide their "latter-day saints" in a great migration to a new Zion in Utah. More pertinently to my interests, I realized while preparing my classes at Columbia University that the Word as America had brought forth a new literary tradition.

Like every other Americanist then, I knew that a national promise had fuelled the classic works of the American Renaissance. F. O. Matthiessen (quoting Whitman) had identified that promise as "Man in the Open Air," and I associated it, accordingly, through a synthesis of Romanticism and modernity, with the new-sprung nationalisms of modern Europe. But in Europe that synthesis obviated time and place confinements. There, Nature revealed its Truths in the Swiss Alps no less than in the English Lake District. 
The United States, however, was "Nature's Nation.” The Truths it revealed confirmed a national history-in-the-making. Thus, the American wilderness called forth schools of landscape painting in which the "open land" from the Hudson River to Niagra Falls, Pike's Peak, and the California mountains were rendered as previews to paradise-to-be-regained. More impressively still, America had called forth a new language - or rather, as Whitman declared, America was itself a vast "language experiment," offering "new words, new potentialities of speech," which would make "Americans the most perfect users of words." By Emerson's decree, "America is a poem in our eyes," and Whitman elaborated: "the United States are themselves the greatest poem."

The audacity of this concept of "poem" carried special force for me because I had first crossed these writers, briefly, in undergraduate courses at Montreal's Sir George Williams College. There, they appeared as provincial offshoots, compatriots-in-letters with Wordsworth, Coleridge, and Carlyle. And in fact I could trace many such links (and had done so, in several comparatist articles). So it came as still another scholarly adventure to discern the odd quasi-allegorical aesthetic of "America." For what Whitman and Emerson meant by "poem" differed from the definitions of Wordsworth ("common man," "poet and solitary reader") and Keats (Beauty/Truth). Nor was it prophecy in the tradition of Blake and Shelley. The poem "America" was neither a Jerusalem of the protean imagination nor a trumpet of universal awakening. Or rather, it combined all of these attributes in a particular national mission. Poetry as America (and vice-versa) was "the star in the constellation Harp which now flames in our zenith" as "the pole-star for a thousand years" (Emerson). It was "the future ... endowed with such a life, that it lives in us even in anticipation" (Melville). According to Carlyle, a major influence on both Emerson and Melville, "Every man that writes is writing a new Bible, or a new Apocrypha," by which he meant the creative spirit (true or misguided) in every writer, wherever or whoever he or she happened to be, in Europe, Asia, or even "barbarous America." In the United States that spirit took a certain national form and a particular identity, as did the promise of newness. Its revelation was an American poetry-to-be, an American poet-to come. Thoreau spoke of that newness as a bridge across the "Lethean" Atlantic, "over which we have had the opportunity to forget the Old World." As the 
promise embroidered by Hawthorne into the Puritan "A," it "foretold" (among its many other meanings) "a high and glorious destiny for this newly gathered people of the Lord."

These writers were very different from one another, each with his distinctive stylistic strategies, and I promised myself to explore those strategies in detail in at least one case. But that project too could wait. ${ }^{6}$ For the moment, I had to explain a difference they all shared from the standard symbolist mode. For in Erich Auerbach's classic formulation, the symbol is a direct interpretation of life, whereas the figura or scriptural "type" presupposes a historical design external to the self. The symbolist, that is, seeks meaning through a subjective interaction between experience and the imagination; the figuralist or typologist assumes a "plot of God," independent of the self - indeed, the Puritans explained, against the self (and its "dangerous" imagination), for the self was fallen, it had to be "denied," "overcome," "erased." The American writers were clearly symbolists, aggressively self-assertive, and yet the symbol of America was just as clearly figural. Lethean Atlantic, destiny foretold: such symbols evoked an earlier tradition; they somehow managed to fuse the symbolic and the hermeneutic modes. "America" mediated between direct experience and prophetic design; its meanings involved a scriptural-modernist reciprocity whereby an intense subjectivity led to a reaffirmation of historical design. Thoreau's "wilderness observations" open into symbols of Romantic nature; he puns on "saunterer," as Blake might, as Sainte Terre, Holy Earth, and he tells us, as Wordsworth might, that "it requires a special dispensation from Heaven to become a true walker." But his walking, in all its aesthetic richness - and in all its spiritual implications, as "Holy Earth" — takes a specific, historical, geographical direction. "Eastward I go only by force," he tells us, "but westward I go free. . . . I must walk toward Oregon and not toward Europe. And that way the nation is moving ... we go westward as into the future."

That too is the direction of the Pequod, symbolically and figurally. Melville's epic explodes into a wondrous plethora of meanings, and at the same time, in a deep sense, it means the American errand into the wilderness. But reading Moby-Dick now I realized that its drama turned on a peculiar strategy, a sinister twist in the redemptive design of the Biblia Americana. Previously, I'd understood that 
malleable grand finale in the Whitmanian mode, as the road ahead, marked by the directive "keep encouraged." Now I saw a dark aspect to that openness. Moby-Dick is a utopian apostrophe to democratic free enterprise and, at the same time, a vision of end-time cataclysm. Teleology in this case meant simultaneously millennium and doomsday. The world's last, best hope might indeed, disastrously, be its last. That volatile polarity gave me pause. Ambiguity on this order had no place in Scripture prophecy. Of course, the millennium had always raised practical questions: when would the it come? how? in what form? - but that it would come, absolutely and forever, was "written in stone." In fact, it was the Answer. Christ might delay, Jeremiah might denounce, but, literally and spiritually, the happy ending was a closed book.

Not so with America: this Scripture-in-the-making pivoted on an uneasy question. Here destiny, because manifest as process, remained uncertain, unreliable. In a trenchant inquiry into that dilemma, Perry Miller asked: "Being an American is not something to be inherited so much as something to be achieved ... Then, why are we so nervous? Why do we so worry about our identity?" That unremitting anxiety had nourished the America literary tradition. "The political Messiah has come in us," Melville declares, then glosses the event as "world's fairest hope, or man's foulest crime." In a brilliant naturalist revision of Edwards's evangelical image of the sun/Son (about to "rise from the West"), Thoreau calls the setting sun "the Great Western Pioneer whom all the nations follow" - and then adds: "else why was America discovered or to what end does the world go on?" Remarkably, this is not a rhetorical question. Or rather, it is rhetorical in a special sense: the power of the symbol as prophecy hinges on doubt. Doubt makes the symbol malleable, open to interpretation and re-vision, but that enriching malleability depends on uncertainty, perhaps chance. It feeds on equivocation and risk. And that relentless "worry" - worry about process (who are we?), nervousness about telos (where are we headed?) - was a foundational constituent of the American Way. To worry about ideals, to be nervous about goals, is to confirm and internalize them; the anxiety is preparatory to self-rededication. In short, the prospect of doomsday fuelled the energies of progress and fortified the rhetoric of continuity through change. It provided the prophetic imperative for the both the errand and the city on a 
hill: dream and nightmare were two sides of the same apocalyptic American coin.

I now saw Melville's epic as central to a distinctive American tradition of dystopia and doomsday novels. Its immediate predecessors were George Lippard's Quaker City (1845) and Cooper's The Crater (1847); its most recent descendant (1968) was Norman Mailer's account of the "motley" Protest March on the PentagonWhale, The Armies of the Night, subtitled, in a fitting image for "America," History as the Novel, The Novel as History. In its poignant "catastrophe," Mailer describes how "God bless America" issued from the "protesting remnant" (walled in the "faceless, ubiquitous" Pentagon) and urges us, as in prayer: "Brood on that country who expresses our will. She is America, once a beauty of magnificence unparalleled, now a beauty with a leprous skin. She is heavy with child ... she will probably give birth and to what? - the most fearsome totalitarianism the world has even known? or ... a babe of the new world ... ? Rush to the locks. God writhes in his bonds."

This symbolic dynamic, promise and threat entwined, differs from that of Moby-Dick. Melville retained the promise, but by indirections - only if we read Ahab's charismatic monomania as a warning to antebellum democracy. So it has been interpreted, but among other contrary signs and omens, the ship's name (an extinct Indian tribe) parodically subverts the very concept of the errand. In this perspective Moby-Dick foreshadows still another variation of the symbolic-figural mode: an American tradition of dead-end, con-man, deadpan humor, from The Confidence Man to Twain's Damned Human Race and Nathaniel West's Day of the Locust. $^{7}$ Mailer's vision of catastrophe, on the other hand, openly summons a "temporarily deranged" country to reclaim its legacy: a mission "forged ... in the forests of the Alleghenies ... Valley Forge . . . Gettsysburg, the Alamo," and now, hopefully, Washington, DC. I recognized in that manic-depressive appeal a certain ritual of socialization: a mode of liberal pluralist discourse that encouraged difference and debate as a means to consensus. But in this case the stakes for consensus had been raised to the pitch of all or nothing: dissent was normative, doomsday prophecy the last, best hope. The "most fearsome" prospect was the most direct road back to the American promise. That formula seemed to me to have 
permeated every level of public discourse. It was a commonplace of electoral politics, a staple of apocalyptic films, a leitmotif of protest songs; it had even reached academia, in scholarly debates over "Civil Religion in America." As the author of that concept, the sociologist Robert Bellah, wrote in 1967, in the journal of the American Academy of Arts and Sciences: "Bewildered and unnerved, when our terrible power fails to bring immediate success, we are at the depth of a chasm the depth of which no man knows" - and from that brink of despair he foresaw a "world civil religion" that would be "the fulfillment . . of American civil religion. Indeed, such an outcome has been the eschatological hope of American civil religion from the beginning. To deny such an outcome would be to deny the meaning of America itself."

"The meaning of America itself": there lay the real threat - to deny the process of fulfillment was to deny hope itself. The solution was the alarm sounded by the prospect of "terrible" failure: a summons to covenant renewal that arose as it were from an abyss, "the depth of which no man knows." That was precisely the strategy I'd noted as a distinctive feature of the New England Puritan jeremiad. I felt I'd found still another project for myself, which once again I deferred. ${ }^{8}$ For the moment I was concerned with a subject impressive enough as testimony to the magnalia of the Puritan imagination: a figural-symbolic aesthetic that could accommodate a wide range of literary expression, from Hawthorne's irony and Melville's “dark Calvinism” to Whitman's euphoria and Stowe's visionary sentimentalism, and whose mutations could be followed in the twentieth century from Fitzgerald's lyric modernism to Pynchon's faux-apocalyptic postmodernism.

Moreover, I now saw, enfolded in that aesthetic achievement, a broader aspect of the legacy. This symbol-figura had provided a model of American identity, a concept of selfhood that was at once unique and inclusive - a "separate, single person," new-born as an autonomous self, detached from traditional communal affiliations, and at the same time the representative of a national errand, "heir to all the past," personifying a New World promise. Rhetorically, that American Self combined the Protestant belief in personal salvation and the Hebrew concept of tribal mission with modern nationalism and its credo of progress. By the mid-nineteenth century, that configuration had evolved from Puritan "visible saint" to the 
Transcendentalist Self-Reliant Man (later, Woman), and within the context of that ideal it was reconfigured over the next century in various molds (to accommodate changing demands and circumstances) as a mainstay of the country's dominant culture. From the Pisgah heights of Emerson's "American Scholar" I could follow a long, multifarious procession of national exemplars, from Mather's Life of Winthrop, "Nehemias Americanus," through Dwight's American Joshua. It led to encompass every social level, every generation of Americans, and every form of "the pursuit of happiness," whether in the Horatio Alger mold (symbol of a rising nation), or as Thoreau's Transcendental "I" ("westward I go free . . we go westward as into the future"), or as a variety of Beat, hippie, and radical "true Americans," including, to my astonishment, in a Yippie skit I witnessed one day on the National Mall, "the martyred idealists Sacco and Vanzetti," flanked by a "Lincoln" on one side and an "Emma Goldman" on the other. Most boldly, and prototypically, there was Whitman's "Myself": "separate . . . en-masse . . . you ... multitudes ... the United States themselves." The epic hero of "Song of Myself" is defined through a constant reciprocity between "I" and "we," mediated by a dazzling play on what be called the American "you" to celebrate interchangeably the private individual ("whoever you are"), the American to come (who will "make things anew"), and an all-embracing national errand.

I proceeded to compare that model of selfhood to its spiritual predecessors - Protestant hagiography, spiritual autobiography, varieties of the saint's life - as well as contemporaneous national types. What I discovered by contrast was a new gestalt, which I called auto-American-biography: the story of one's self as symbol of America, as in Walden or Colin Powell's An American Journey. Its transmutations constitute a map of ritual acculturation in the developing nation: for the Puritans it served to combine New England and American identity; in the Great Awakening it linked evangelical rebirth and a proto-national mission; with independence, that literal-spiritual figure helped sanctify the concept of representative government; and with the growth of capitalism, it expanded to incorporate an economic belief-system. The major contrasts were two sources that Emerson explicitly debated. One was "individualism," a term introduced by nineteenth-century French socialists to denounce the callous, dehumanizing system of 
capitalist self-interest. The other was "individuality," the Romantic vision of Genius, in which the uniquely gifted individual, the spiritual aristocrat, somehow embodied Volksgeist (Goethe as representative of German Kultur, Pushkin of the Russian Soul). The American model inverted both these concepts. Romantic individuality was transformed from "spiritual aristocracy" to mean a figure of spiritual commonality (whose uniqueness lay in his determination to do his "own thing" his "own way"), and individualism was enshrined as self-interest to signify a cultural ideal of personal selffulfillment.

The grand synthesis of this unlikely fusion of political-spiritual opposites was a chameleon figure, forever mobile and vaguely "middle class" (as denoting a democratic average more than a certain income), a "typical American," whose private narrative made manifest a national dream. I recognized in that figure a source of the enormous energies of enterprise that in a century and a half had raised the United States from colony to world power. I also recognized in it the distinctive qualities of American individualism, both systemically, as the rites of democracy, and personally, as the rights of self-fulfillment. For unlike any other secular society, the socioeconomic system represented by the American Self had neither social nor economic distinctions. In place of those restrictive Old World structures, it called for an open democracy, without privilege or class barriers - an amorphous, presumably endlessly mobile "middle class" society whose levels of wealth and power signified degrees of self-realization. So understood, the facts of economic and social discrepancy did not discredit the rhetoric of self-fulfillment. On the contrary, they confirmed the rhetoric by revealing the open-endedness of the system at large. They were visible signs of your mobility, proof by implication of the prospects potentially awaiting all Americans (or their children). In the early republic, under the ethos of "deference," that open structure built upon the principles of meritocracy. But as the nation expanded, the rhetoric of the American Self increasingly diffused (blurred, conflicted with) that concept of inherent hierarchy. For meritocracy evoked Old World distinctions and constraints: elite versus demos, common versus uncommon, ordinary versus extraordinary. And rhetorically, success in America was available to all. Examples of success were to be identified with, not envied or submitted 
to, and through identification they were to be celebrated as confirmations of equality, proof-texts of your possibilities. The exceptional talent represented an exceptional nation, from the "model Ben Franklin" to the most recently "discovered" Hollywood star, all typical Americans.

Of course, success involved uncertainty. The popular story always hinged, in Horatio Alger's formula, on "luck and pluck," or, in Emerson's terms, on "risk and renewal." What the world admired as "American optimism" carried with it the Puritan doomsday anxiety: not to succeed as an American was to fail, catastrophically. Elsewhere failure was normal - in a religious sense, even honorific (the poor who were "always with us" were also to "inherit the earth") - and, after all, America was populated by "huddled masses" of the world's failures. But here they would not fail: that would contradict the very purpose of immigration. Failure was unAmerican.

One living result of that stigma was captured in a slogan of the Radical Sixties: "violence is as American as apple pie." That was a psychological consequence. Its economic counterpart was the belief that, as an un-American story, failure excluded you from national concern. It was the secular mark of those whom the Puritans had designated as visibly not one of the elect. Then, the stigma excluded you, like the unrepentant Hester, from the community of saints. Now, that stigma took a specific social form: the resistance in the United States to what Alan Greenspan, chairman of the Federal Reserve, labeled "welfare statism." Failure was personal; symbolically it recalled the way of the Old World. Success was the American Way. Its Representative Individual was the symbol incarnate of the New World. Once, in another, theological vocabulary, it stood for the Puritan "Americanus": a saint in process, whose worldly "works" made visible both his spiritual calling and a historical mission. Mather eulogized Winthrop's governorship by linking him back to the scriptural Nehemiah, who had led the chosen people out of exile to their promised land and rebuilt the walls of Jerusalem - a figural link that also recast Winthrop's success in New England as a preview of American progress. Through the several symbolic transformations, designed to accommodate independence, industrialization, and the post-Civil War "incorporation of America," that figure had emerged as the focal point of the national narrative, 
representing the manifest promise of a model democracy and the future of humanity, while at the same applying directly, uniquely, to you, as the American Self.

I had found my subject. By what rhetorical magic had the $\mathrm{Pu}-$ ritan influence issued in that charismatic identity, no less appealing abroad, as the "golden door" of opportunity, than it was internally, as a summons to national unity. This book is the result of my inquiry into the evolution of a cultural text, a centuries-long process of symbolic transmutations, canon-formation, and narrative development. I thought of it, in Whitman's sense of America as a language experiment begun - a venture in rhetorical self-creation launched in 1630, when a group of Non-Conforming Reformers, financed by the Massachusetts Bay Company, Incorporated, imbued with the "Protestant work ethic," lured by colonial opportunities, fired by the radical spirit of English Puritanism, lifted by the millennial dreams of the Reformation, emboldened by revolutionary advances of early modernism (in technology, navigation, natural science, the printing press), animated by the utopianism of an age of discovery - when that company of seven hundred Dissenters, enraptured (theologically as well as imaginatively) by the prospects of a New World, named themselves Americans, in contrast to all other colonists (who reserved that term for the "native savages"), and then proceeded to inscribe an identity of newness for the American to be.

Looking back on the time since 1975, I see the familiar proof-texts, duly reconfigured, throughout the culture: in Tea Party demands to "reclaim America"; in Liberal-Left defenders of "mainstream American values"; in waves of immigrants enticed as ever by the "American promise"; in TV talking heads explaining political corruption and economic greed as a betrayal (evidence to the contrary notwithstanding) of "what America means"; and in the quasi-scriptural rhetoric (echoing the earlier quasi-apocalyptic confrontation with "atheist Communism") of the "war on terror." Perhaps most tellingly, the rhetorical legacy was manifest in the increasing recourse to religion during times of crisis - on every cultural level, from gospel and folk songs to specialized TV channels; best-sellers such as Laurie Beth Jones's Jesus, CEO; blockbuster movies; and public demonstrations of faith "in times of financial and moral distress": "God's words, the 
concept of godly government, are woven into the warp and woof of the fabric of our nation."

In its secular political form, that rhetorical tradition seems implicit even in the radical demands of our time (as it was in the Radical Sixties): for example, in the appeals to "American rights" as moral imperatives by gays, lesbians, "post-seventies feminists," and defenders of "freedom of choice" no less than proponents of "right to life." In any case, I heard the tradition affirmed clearly and eloquently, this time without surprise, in the rhetoric of Barack Obama. Transforming the complex dreams from his temporary immigrant father into the Dream from the Founding Fathers, he proclaimed the bonds of black and white, which he embodies as flowing from a national faith (one that merged all other skin colors); stressed the "deep need for religious belief" (as a national ideal that accommodated all religions); and celebrated a "chosen land" in which "there are no red states or blue states, but only a United States" with a mission. The Candidate of Change, "change we can believe in," he had been summoned, he said, to "restore our image as the last, best hope on earth." As a citizen I voted for Obama and rejoiced in his election. As a scholar I continue to keep my skeptical distance from that American Self.

The response to the publication of my book was generous beyond expectation, but I was warned even then of attacks to come. When they came a decade or so later, they left me feeling frustrated rather than embattled: my critics focused on what I thought I could take for granted. I hope that this preface will set the record straight. My book seeks neither to praise the "Puritan mind" nor to debunk the "Puritan experience." It is neither a patriot's celebration of "American exceptionalism" nor an antagonist's exposé of false myths. This is a scholar's attempt to convey a certain creative achievement, the intricacies of an extraordinary resilient literary-cultural work of the imagination. It may be worth adding, at the risk of stating the obvious, that that achievement is not unique. Other cultures have created symbolic identities just as impressive for their imaginative reach and persuasive powers. The American Self, and the national/personal promise it represents, is the distinctive creation of a New World. To borrow Fitzgerald's 
vision of what it meant to discover America, it was an "aesthetic contemplation ... commensurate to the [modern] capacity for wonder."

To be sure, the Puritan rhetoric competed with other claims to national identity. Residual forms of feudalism lingered and adversarial ideals (Fourierist communalism, "Communism is twentiethcentury Americanism") were advanced from time to time. And as the early classics of American Studies demonstrate, myths and symbols had been imported in the seventeenth century from legendary Arcadia and the fabled terrestrial paradise, from Athens, Rome, and Elizabethan England. Some of these subsumed the Puritan rhetoric in agrarian naturalism, or in visions of an ecological paradise. In other cases, they seem to me to have been incorporated into the Puritan vision, in the form of ecological end-time disaster or, conversely, of a historically redemptive innocence set against Old World depravity (as in the typical American Abroad, from Melville's Redburn and Hawthorne's Marble Faun through James's The American). In any case, it was the Puritan vision that became the language of the dominant culture.

As such, the rhetoric of America has had large-scale practical consequences, for good and for evil. It has sanctified ideology as religion, banning as heresy all social and economic alternatives to capitalism, and making utopia itself captive to its beliefs. And it has enabled ideals as profound and perhaps as enduring as those of any earlier belief system, among them ideals capacious and volatile enough to challenge fundamental norms. The American immigrant experience testifies both to exclusion (and reemigration) and to America's beneficence as "Mother of Exiles." The expansionist errand has wrought havoc around the globe, and it has generated a remarkable generosity of spirit and material aid. The American Self served to brand, ghettoize, victimize, and plunder, and it assured every child - at first white Protestant boys, but then also Catholics, Jews, girls, and African-Americans - that she or he might become president, with such persuasive force that, representatively, it came to pass. And the aesthetic strategies inscribed in those ambiguities are writ large in a literature that at its height takes its distinctive place among the great literatures of the world.

As for my critics, I welcome their enormous contribution to our understanding: both the alarming annals of barbarism opened by 
the New American Studies and the enriching archives of civilization uncovered by Multi-Cultural Studies. No doubt their critiques may have led me in some cases - notably, my focus on what was then the canon of American literature - to qualify my argument and to acknowledge other rhetorical traditions. More often, I believe, I could have expanded my argument by incorporating materials that their research has brought to light.

In any case, I have no wish to enter into polemics. Instead, I would like to make amends here for the excessively terse acknowledgements in the previous edition. Several senior scholars supported me from the start: Edwin Fussell, David Levin, Edmund Morgan, and Roy Harvey Pearce, and one of them, Daniel Aaron, a founder of American Studies, has remained a lifelong friend. Later, as I reached beyond the Puritans, I found encouragement from "younger" Americanists, in particular Michael Colacurcio and Alan Trachtenberg, then emerging as leading figures in (respectively) the intellectual and the cultural areas of American Studies. Still later, I felt fortified by the response of a new generation of scholars, including two close friends, the late Emory Elliott, a central figure in International American Studies, and my current Harvard colleague, Werner Sollors, who has shaped the field of Ethnic Studies.

In the course of defining auto-American-biography my first Ph.D. student, Lyndall Gordon (now a distinguished Oxford biographer) directed me to provocative contrasts in Buddhist autobiography, and in annotating Mather's Life of Winthrop my research assistant, Lawrence Rosenwald (a classicist, now a prominent Americanist), helped with Greek and Latin. Discussions with my colleague at Columbia, Robert Hanning, guided me through the thickets of medieval hermeneutics, and another Columbia colleague, Michael Wood, suggested the title. My students-become-scholars (and often friends) are too many to name individually, but they were then and remain the vital core of my Americanist community.

Finally, a private note. The completion of this book was delayed for several years by personal priorities, involving the prolonged illness of my daughter Aliza. I dedicate this new edition to her memory. 


\section{Notes}

1 The exception was Edward Taylor, who had come late to New England (1688) and, though an "old guard" preacher, was considered by critics to have been secretly unorthodox, probably best classified as an English metaphysical poet, with perhaps Catholic leanings. I was unaware at the time that two scholars were already exploring Puritan typology: the German Americanist Ursula Brumm, in American Thought and Religious Typology, published in 1963, but not translated into English until 1970 (New Brunswick, N.J.: Rutgers University Press) and Jesper Rosenmeier, "The Image of Christ: The Typology of John Cotton" (Harvard dissertation, 1966), from which an essay was published in 1974. In time I discovered still other scholars engaged with "early American literature," and gradually we formed a small community of "American Puritanists" bent on what we felt was a new venture in American Literary Studies. I gathered examples of this enterprise in two volumes I edited, each in its way preparatory to this book: Typology and Early American Literature (Amherst: University of Massachusetts Press, 1972) and The American Puritan Imagination: Essays in Revaluation (London: Cambridge University Press, 1974).

2 I refer to the literature of the Puritans who came to Boston in 1630, who were followed over the next decade by immigrants who spread across New England. They called themselves Non-Separating Dissenters because they hoped by example to redeem European Protestantism. I distinguish them from the Plymouth Pilgrims, an insulated group of about a hundred Separatists following a particular pastor, William Brewster, from Leyden, Holland, who had come in 1620 to "worship in peace." What they meant by "Pilgrim" was staple Christian allegory: the personal journey to God through a world of sin to the promised land of heaven. During the nineteenth-century process of myth making, the fundamental difference between the two groups blurred and reconfigured in various ways, but always in some form of paternity ("fathers," "forefathers," "progenitors").

3 Bancroft actually refers in this sense to Mather's epic. The continuities this implies are worth noting in their own right as proof-text of the Puritan influence. One example must suffice: the "happy hour" Harriet Beecher Stowe records, when her father "set up in his bookcase Cotton Mather's Magnalia, in a new edition of two volumes. What wonderful stories those! Stories, too, about my own country. Stories that made me feel the very ground I trod on to be consecrated by some special dealing of God's providence ... the glorious future of the United States of America ... commissioned to bear the light of liberty and religion through all the earth and to bring in the great millennial day. The millennium was ever the star of hope in the eyes of the New England clergy. ... They were the children of the morning."

4 Lincoln's Gettysburg Address would make for an exemplary case study in the process of canonization I've been suggesting. I refer to the "classics" that shaped and circumscribed the open-ended, malleable America-text-the phrases, catch-alls, narrative-evoking "cultural key-words" - that gather currency, circulate though various social levels, and then, ritually, over genera- 
tions, cohere into an ongoing national Scripture. In Lincoln's case, the Gettysburg Address at first received scant and mixed reviews. One of the most positive responses came from the partisan Republican (Springfield, Mass.) newspaper, which remarked that (as a two-minute performance) the Address would "repay further study as the model speech." In an important stage of canonization, after Lincoln's assassination, George Bancroft singled it out as a "New Testament," dwelling on the centrality of the (disputed) words "a nation ... under God" in conjunction with the "reverential" opening to the revolutionary "fathers." Whitman was present at the Address as a reporter but took no notice of it. It remained for another great poet to celebrate the Gettysburg Address as "a symbolic and sacramental act" foreshadowing Lincoln's "sacrificial act of death and rebirth." Robert Lowell was himself of course building on a national text-including Whitman's later canonical homage - in which "our martyred president ... was God's chosen one."

5 This project began with a series of essays (1975-79) and continued in two collections of essays I edited with Myra Jehlen - Reconstructing American Literary History (Cambridge, Mass.: Harvard University Press, 1986) and Ideology and Classic American Literature (Cambridge: Cambridge University Press, 1986) - and later in a long theoretical essay "Games of Chess: A Model of Literary and Cultural Studies," in Centuries' Ends, Narrative Means, ed. Robert Newman (Palo Alto, Calif.: Stanford University Press, 1996), pp. 15-58, 319-29. These publications were followed by a number of specific applications of that "model" (1997, 1998, 2000, 2002).

6 The result was The Office of The Scarlet Letter (Baltimore: Johns Hopkins University Press, 1991) as well as essays on Melville and Emerson collected in Rites of Assent: Transformations in the Symbolic Construction of America (New York: Routledge, 1993).

7 I examine aspects of this tradition in "Deadpan Huck, or What's Funny About Interpretation" Kenyon Review 24 (2002), pp. 90-134; reprinted in collections of essays edited by Gerald Graff and James Phelan (2004) and Harold Bloom (2006).

8 This project, which had begun in an entirely different vein with a monograph cumbersomely entitled (after a phase from Melville) "Horologicals to Chronometricals" (1970), issued as The American Jeremiad (Madison: University of Wisconsin Press, 1979.) 
This page intentionally left blank 